\title{
Crisscrossing Textbook Writing Tasks and Core Values of Education Students in an Outcomes-Based Education Platform
}

\author{
Jovar G. Pantao* \\ College of Education, Mindanao State University \\ Fatima, General Santos City, Philippines \\ *jovar.pantao@msu.gensan.edu.ph
}

\begin{abstract}
This study aimed to describe the core values observed among education students during their textbook writing journey. This study employed concurrent triangulation mixed method design wherein quantitative data were generated from survey while qualitative data were taken from reflective questions responses of the students. Survey questionnaires and reflective questions were answered online by one-hundred thirtysix (136) Bachelor of Elementary Education students of Mindanao State University General Santos City who were officially enrolled in Assessment in Learning 1 during the 1st Semester of the Academic Year 2019-2020. With the commitment to OBE implementation, the four sections were divided into small groups and were tasked to demonstrate constellations of fundamental life performance roles to produce textbooks in Araling Panlipunan for elementary pupils. Observations made during tasks supervision showed that the students demonstrate Filipino core values as they work to produce the textbook. The survey findings revealed that the students during textbook writing journey always demonstrate respect, nationalism, sense of responsibility, sensitivity, solidarity, and resilience however they had tendencies to play fairly in managing their time and in utilizing resources wisely and judiciously. Similarly, the observed Filipino values reflected in survey response were supported by the students' responses from the reflective questions. Records of observations also showed comparable convergent results. Generally, the textbook writing activity is instrumental in developing the Filipino core values such as Maka-Diyos, Makatao, Makakalikasan at Makabansa. Hence, the study recommends for the analysis of the academic outcomes of the pre-service teachers before and after the textbook writing activity.
\end{abstract}

Keywords - crisscrossing, textbook writing, core values, preservice teachers, Outcomes-Based Education

\section{INTRODUCTION}

Higher Education Institutions in different nations across the globe are exploring new ways of designing curriculum to respond to the changing demands of the world. They are continuously exerting efforts to produce graduates who are equipped with professional skills, knowledge and attributes that are quintessential in responding to the needs of the society. In fact, higher education community has been doing their task of retrofitting their instructional approaches, methodologies and strategies to align them with student learning outcomes. They focus attention recently on course outcomes and on assessing the performance of the students authentically.

To ensure that the graduates cope with the qualifications and standards of the 21 st century students, the Commission on Higher Education (CHED) in the Philippines orders for the adoption of the Outcomes-Based Education. Through Memorandum 46, s. 2012, the CHED requires all higher education institutions to enhance quality assurance by pursuing Outcomes-Based Education and Typology-Based Quality Assurance [1]. This paradigm of education is focused on what the educational system want the students to demonstrate successfully.

In response to this order, many Teacher Education Institutions in the country have been designing instruction for pre-service teachers using the OBE frame in articulating learning outcomes, planning and implementing authentic tasks as well as in pursuing student-centered approach. In fact, the curricula offered for future educators are aligned with the Philippine Professional Standards for Teachers (PPST) to make sure that all graduates of teacher education programs are ready for the demands of the Department of Education.

Under the new curriculum of the Bachelor of Elementary Education Program of the College of Education in Mindanao State University, one of the subjects to be taken by the students is CPE105 with the descriptive title, Assessment in Learning 1. This course is focused on principles and utilization of basic assessment tools to improve the teaching learning process. In this course, students using the Task-Based Learning approach were tasked to perform collaborative writing of textbook for them to demonstrate their knowledge on designing, selecting, organizing, and using diagnostic, formative, and summative assessment strategies which are consistent with curriculum standards in Araling Panlipunan subject offered for the elementary learners. In this task, preservice teachers performed most of the fundamental life performance roles enumerated in the Life-Performance Wheel. 
While the students were honed on the assessment and reporting of students' learning in this course, the collaborative writing of textbook was also considered as an avenue for the pre-service teachers to develop Filipino core values as stipulated in the Republic Act 8491 national motto which is, Makadiyos, Makatao, Makakalikasan at Makabansa. The Department of Education community is expected to embody the four Filipino core values enumerated in the motto and teachers are expected to integrate these in delivering their lessons for the elementary pupils.

Given the agenda of Outcomes-Based Education, there is really a need for the students to be fully involved in the process of teaching-learning to better develop their knowledge, skills and attitudes. Collaborative textbook writing was anticipated to satisfy this need by involving the preservice teachers at every phase of producing the textbook for the elementary pupils. The engagement of the students into this task was also argued to be an influential strategy to develop the Filipino core values among the pre-service teachers. In fact, scholars presented findings that when students are engaged in active learning process, they are most likely to develop the attitudes which they can demonstrate during and at the end of the educative process [2]. Also, textbook writing as authentic task is also argued to help because previous study of Kocyigit and Zembat 2013 unleashed that the use of authentic tasks is contributory to the development of positive attitudes. One study also indicated that application of task-based learning is very effective in the development of scientific attitudes [3]. Despite these considerable findings of previous studies, the contribution of textbook writing to the Filipino core values development of the pre-service teachers was not yet validated. With the aforementioned, this research was conceptualized to describe the observed extent of Filipino core values exercise of the education students during their textbook writing journey.

\section{REVIEW OF RELATED LITERATURE}

Outcomes-Based Education (OBE) has been the focus of Higher Education Institutions recently. Many colleges and universities have been switching the process of learning to produce that graduates who are equipped with appropriate knowledge, skills and attitudes needed in the labor market. With this, the Commission on Higher Education (CHED) in the Philippines continues to harmonize the environment of higher education in response to this transformation challenge. The commission initiates bold initiatives which include the move to pursue OBE [4].

Outcomes-Based Education according to Spady, Hussain, Largo and $\mathrm{Uy}$, is an education that is done based on the outcomes the students are expected to demonstrate successfully. The education under this frame looks like and does depend on those outcomes [5]. Spady, defined it as an education that is clearly focused and organized on everything that is essential for the students to demonstrate successfully after the implementation of the teaching-learning process [5]. The term OBE comes from the constructivist theory according to Jani, Abdul Latif, Talib, \& Mohd-Is that drives the learners to utilize self-activities as a process of building their knowledge, as interpreted through their existing scheme. In essence, the learning under OBE platform is actually the outcomes of the activities and experiences engaged by the students [6].

Outcomes-Based Education operates in four principles: 1) clarity focused on outcomes of significance; 2) expanded opportunity for all to succeed; 3) High expectations for all to be successful and 4) design down from where one wants to end up [5]. Meaning, all activities in the frame of OBE principle are directed towards the outcome of teaching not on what is going to be taught. These activities are supposed to pay attention to what the learner is supposed to do and at what standard it is based. That is why the activities are designed to equip the learners with the knowledge, competence and orientations needed for success after they leave institution [7].

OBE has been recognized as the most significant educational component of societies with a knowledge-based economy. For instance, the Canadian Higher Education believes that in order to stay globally competitive, it is necessary to significantly shift toward this OBE system. In Malaysia, constructive alignment was already introduced to the Teacher Education Institutions since 2015 to incorporate the aspects of Program Education Objectives (PEOs), Program Learning Outcomes (PLOs), the calculation of Student Learning Time (SLT), Technology Pedagogy Content Knowledge (TPCK) and soft skills. However, the implementation of constructive alignment remained a question mark [6].

There are also tertiary institution which started to take actions towards the implementation of OBE. For instance, the Technological Institute of the Philippines initiated actions for the implementation of the OBE. The institution facilitated the dissemination of information about the nature of the OBE, alignment and mapping of the curriculum, assessment of output aspect and quality instruction improvement [7].

Moreover, the model of Outcomes-Based Education which the academic institutions adopt has a primary focus of facilitating the changes within the learners rather than on the results of the test and course grades. Recently, efforts on restructuring the curricula, course content and delivery, and assessment strategies have been initiated by many higher education institutions in the country for the learners to increase their knowledge, develop their skills as well as influence positively their attitudes, values and judgment [8].

According to Mercado and Lagto, the Higher Education Institutions in the Philippines find the principles of $\mathrm{OBE}$ significant. In fact, they strongly agree as revealed by research work that OBE-based instructional strategies expand the motivation or purpose of technology beyond awareness and understanding levels [4]. The primary purpose of OBE is to lead the learners to the desired changes. It generally operates on the idea that learning is best when the desired outcomes are determined first. In this designing down process, strategies, 
processes and techniques are then identified after the end goal has been determined [9].

However, the shift to this OBE system requires reconfiguring the paradigm of teachers in implementing their pedagogical repertoire. The role of teachers under the OBE is to motivate the learners to actively participate in the activities and reach the learning outcomes. This major role of educators requires support from the authorities to concretize and better implement the desired curriculum and approaches because the implementation of OBE demands commitment from various education stakeholders [10].

The establishment of this OBE system can help facilitate the students to achieve the desired outcomes [10]. Aside from that, OBE is also characterized by authentic tasks, studentcentered approaches, and competencies and skills-focused learning [11]. The core of the learning process in OBE atmosphere are the students and this suggests outputs and outcomes are yielded when learner-centeredness is considered essential in the implementation of instruction. Research revealed that student centered activities in Teacher Education Institutions do stimulate and promote analytic and critical thinking and development of active individual and group participation [12].

One of the student-centered activities which can be facilitated in the OBE class is writing. In this study the students were tasked to write learning modules as part of the textbooks they were expected to produce. There is a wealth of literature communicating that writing activities do contribute to the development of the learners. For instance, one study added an empirically established findings that writing extends its impact to personal and social development [13].

Other than that, there is this sound template for futurefocused OBE which is called Life-Performance Wheel. The wheel contains rich range of role-performance abilities which every individual in every field needs nowadays. In the text book writing tasks accomplished by the students, they performed fundamental life performance roles as listeners and communicators or as learners and thinkers. All of them played the role of the creators and producers, planners and designers, implementers and performers and problem finders and solvers.

They also played the role of team members and partners, leaders and organizers, supporters and contributors as well as teachers and mentors. Generally, the textbook writing made the students demonstrate the essential performance components of OBE which are: self-directed learners, collaborative workers, complex thinkers, community contributors and quality producers [5].

Self-directed learning is among the features of OBE learning and this pedagogical method was found effective by scholars in reinforcing the values of the learners [14]. There is also a wealth of literature that authentic learning is evident in OBE platform. In this study, textbook writing can be considered authentic learning because students played the role of textbook writers who will produce books for the elementary learners. This nature of OBE can possibly crisscross with the values development as findings of the research in line with authentic learning uncovered that this kind of learning can increased the success of the teacher candidates. With authentic learning teacher candidates increased their self-directed learning skills from moderate to high level [15].

OBE platform is also promotive of cooperation. Because OBE promotes active learning, cooperative learning must be evident in realizing this. In fact, cooperative learning is considered as the foundation of active learning as many of the active learning procedures such as team learning, problembased learning and collaborative learning necessitates the learners to work in cooperation with their group mates to achieve their collaborative learning goals. In this study, groupings of small groups to work in cooperation in producing the textbook is considered. Including the concept of collaboration in textbook writing is grounded on social independence theory. Many studies validated the argument of the theory that cooperation results in more positive relationship among the learners has been validated by many studies [16].

There is also an assumption that pre-service teachers may develop the Filipino core values during their textbook writing journey as extent of exercise of core values is associated with the extent of integration in their lessons when they get to the field of teaching. One study which determined the influence of the extent of exercise of the core values along Maka-Diyos (Godly), Makatao (mindful of humanity), Makakalikasan (respectful of nature) and Makabansa (patriotic and nationalistic) to the extent of integration of such by the Grades Five and Six Social Studies teachers in the District of Bolinao, Pangasinan, Philippines yielded result that is affirmative to the assumption. The findings of the study revealed that the teachers in District of Bolinao moderately exercised the core values along Maka-Diyos, Makatao and Makabansa while the core value Makakalikasan was slightly exercised. The study also revealed that core values along Makadiyos, Makatao and Makabansa were integrated by teachers to a moderate extent while the Makaklikasan core was integrated to a slight extent The result further uncovered that the extent of exercise of the core values influences the extent of integration of the core values to lessons implemented by the Social Studies teachers.

\section{TeXtbook Writing Activities}

The textbook writing tasks of the pre-service teachers in Assessment in Learning 1 involved different activities, to wit:

\section{A. Setting of the Goals and Objectives}

The pre-service teachers enrolled in CPE 105 claases were oriented about the textbook writing tasks during the first day of the class. On that day, each of the four classes was divided into five )5( groups. In every class, one group was assigned for particular level to write for each of the following grade levels: Grade1, Grade II, Grade III, Grade IV, and Grade V. During the thirty $) 30$ ( munities orientation, the course instructor facilitated the class discussion for the class to agree on the 
goals and objectives they need to realize as they accomplish the task of producing a textbook in Railing Panlipunan. Timeline for submission of outputs was also mapped during that day.

\section{B. Review of the K to 12 Curriculum}

The students were also asked to download a copy of the $\mathrm{K}$ to 12 Curriculum in Araling Panlipunan. Groups of writers were given time to review the competencies and learning content of the Grade Level they are to work on. They then accomplish the matrix of assignment for the authors. Generally, each member of the group were assigned to write three Aralin (Lesson) as their contribution to the book which they were tasked to produce.

\section{Consultations and Mentoring}

The course instructor of CPE 105 facilitated consultations and mentoring sessions for the groups of textbook writers to assist them in accomplishing their tasks. In these sessions, the course instructor provides inputs and tips in textbook writing as well as manage conflicts encountered by the group of writers.

\section{Learning Sessions}

The textbook writers also attended sessions on assessment principles and theories as well as on designing diagnostic, formative and summative assessment strategies every Monday. There were also sessions on writing textbooks for elementary pupils with focus on lay outing, content development and use of appropriate language.

\section{E. Workshops}

Every Thursday, the students were assigned to draft and outline the content of the modules assigned to them. These drafts were usually presented to their group members for critiquing and suggestions. The drafts were also presented to the course instructor for checking and additional inputs.

\section{F. Writeshops}

The writers of the books also underwent intensive workshop to produce the textbook. For the entire semester, there were series of write shops which the pre-service teachers percolated. These write shops were either done in the class or remotely

\section{G. Book Evaluation}

Drafts of the textbooks were submitted to three (3) evaluators of the Learning Resource Management and Development System of the Department of Education-General Santos City. The textbooks produced by the students were evaluated using the Screven Consumer Oriented Evaluation tool.

\section{H. Editing}

From the comments and suggestions of the evaluators, the writers edited the sections of the textbook for cohesion of structure as well as the clarity and design of the visual elements. Punctuation, grammar, syntax and spelling were also edited.

\section{Book Launching}

The culminating activity of the textbook writing activity was a program to launch the contextualized books in Araling Panlipunan. The activity came with a book exhibit as evidences of their demonstration of appropriate knowledge and skills in developing and utilizing assessment tools to improve the teaching-learning process.

\section{RESEARCH METHOD}

\section{A. Research Design}

This study employed concurrent triangulation mixed method design wherein findings generated were generated by each method through the evidences produced by the other methods. In this study, quantitative data were generated from online survey using the modified Filipino core values scale to describe the Filipino core values displayed by the pre-service teachers. Similarly, reflective questions were also rolled out online to generate qualitative responses about how the preservice teachers demonstrated the Filipino core values in producing Araling Panlipunan textbooks. Observations were also made once a week from August 2019 to December 2019 during tasks supervision and consultations to acquire direct and primary evidences of students' demonstration of the Filipino core values. This approach is appropriate since the purpose was to use the different methods to support each of the methods' findings to arrive at the accurate descriptions of the Filipino core values evident among the pre-service teachers.

\section{B. Respondents}

The respondents of this research were one-hundred thirty six (136) out of one hundred sixty four (164) Bachelor of Elementary Education students of Mindanao State University General Santos City who were officially enrolled in Assessment in Learning 1 during the 1st Semester of Academic Year 2019-2020. These students were chosen regardless of age, gender, ethnic affiliation and socioeconomic status. The criteria for inclusion included official enrolment to four (4) CPE 105 classes with the following class schedules: 7:30-9:00 AM, 9:00-10:30 AM, 12:30-2:00 PM and 2:30-4:00 PM every Monday and Thursday. Originally, all students officially enrolled were targeted as respondents however there were three (3) students who dropped the subject and twenty eight (25) students who chose not to participate in the study.

\section{Sources of Data}

The data for this research included online survey data and online reflective questions responses from one hundred thirty six (136) pre-service teachers. Data from the observation checklist accomplished during task supervision were also among the sources for this study. Further issues were also clarified by asking confirmatory questions to some students. 
Concurrent triangulation was done by comparing the data obtained from the different methods employed in this study.

\section{Data Analysis}

Descriptive statistics such as frequency distribution and weighted mean were used to quantitatively analyze the gathered data. To describe the pre-service teachers 'extent of exercise of the core value such as Makadiyos, Makatao, Makakalikasan and Makabansa during their textbook writing, the scale below was used.

TABLE I. THE SCALE

\begin{tabular}{|l|l|l|}
\hline Point Value & Statistical Limit & \multicolumn{1}{c|}{ Description } \\
\hline 4 & $3.50-4.00$ & Always Observed \\
\hline 3 & $2.50-3.49$ & Sometimes Observed \\
\hline 2 & $1.50-2.49$ & Rarely Observed \\
\hline 1 & $1.00-1.49$ & Not Observed \\
\hline
\end{tabular}

Qualitative data were analyzed using the six-phase thematic analysis outlined by the framework of Braun and Clarke. The analysis looked into the complementation of the responses of the pre-service teachers to the findings of the survey. Observation checklist were also used to validate the result of the online survey.

\section{RESULTS AND DISCUSSION}

\section{A. Makadiyos}

Table 2 indicates the displayed indicators of Makadiyos core value observed during the textbook writing tasks of the preservice teachers. These indicators are summarized into two main categories: 1) expresses one's beliefs while respecting the spiritual beliefs of others and 2) shows adherence to ethical principles by upholding the truth.

TABLE II. Observed MaKadiyos Core VAlues Among Pre-Service TeAHERs

\begin{tabular}{|c|c|c|}
\hline Indicators & Mean & Description \\
\hline \multicolumn{3}{|c|}{ A. Expresses one's beliefs while r especting the spiritual beliefs of others } \\
\hline 1. Engages oneself in worthwhile spiritual activities & 3.42 & Sometimes Observed \\
\hline 2.Respects religious beliefs of other members of your group & 3.92 & Always Observed \\
\hline 3. Respects sacred places & 3.84 & Always Observed \\
\hline Mean & 3.73 & Always Observed \\
\hline \multicolumn{3}{|c|}{ B. Shows adherence to ethical pri nciples by upholding the truth } \\
\hline 4. Tells the truth & 3.43 & Sometimes Observed \\
\hline 5. Returns borrowed things in good condition & 3.68 & Always Observed \\
\hline 6. Demonstrates intellectual honesty & 3.57 & Always Observed \\
\hline 7. Expects honesty from others & 3.34 & Sometimes Observed \\
\hline 8. Aspires to be fair and kind to all & 3.76 & Always Observed \\
\hline 9. Identifies personal biases & 3.31 & Sometimes Observed \\
\hline $\begin{array}{l}\text { 10. Recognizes and respects } \\
\text { one's feelings and those of others }\end{array}$ & 3.79 & Always observed \\
\hline Mean & 3.55 & Always observed \\
\hline Overall & 3.64 & Always observed \\
\hline
\end{tabular}

As shown in table 2, a significant number of Makadiyos indicators were observed among the pre-service teachers. While accomplishing the textbook writing tasks, they always express their belief while respecting the spiritual beliefs of others (3.73). This was evident whenever discussions and meetings they had with their groupmates when religion is directly or indirectly touch. For example, when the modules they make includes concepts of religion and when they consider prayer time when they agree on the schedule for work.

Generally, the CPE 105 students always show adherence to ethical principles by upholding the truth (3.79). This was observed in the works they submitted as they always do referencing and citation of the works they include in the book they are producing. Many of them were also observed to be clarifying what needs to be done when they honestly recognize that they have confusions about the tasks. Some students reflected that they need to have honesty in everything they do because this can help them improve their teaching practice.
When they borrow things which they need for example books and references, they return these in good condition.

It can be noted from the results that there are some indicators of Makadiyos Core Value which the pre-service teachers sometimes observe. These are: 1) engages oneself in worthwhile spiritual activities $(3.42)$; 2) tells the truth $(3.43) ; 3)$ expects honesty from others; and 4) identifies personal biases. The display of these behaviours were found to be not at all times evident because these indicators are not at all times needed in the production of textbooks.

With regards to telling the truth, some pre-service teachers disclosed that there are some truths which they need to keep confidential. They respect when their group mates need spaces for these truths to be kept. That is why they also do not expect their classmates to be sharing all the truths especially when these are not related to their goal of finishing their textbook writing task. They also have reservations in sharing their personal biases as they need to blend well with their groupmates in order to be successful in realizing their goal 


\section{B. Makatao}

Table 3 presents the indicators of Makatao core value observed during the textbook writing tasks of the pre-service teachers with corresponding mean and decision classification. These indicators are summarized into two main categories: 1) displays sensitivity to individual, social and cultural differences; and 2) demonstrates contribution towards solidarity.

TABLE III. ObSERVEd MaKatao Core VAlues Among PRE-Service TEAHERS

\begin{tabular}{|c|c|c|}
\hline Indicators & Mean & Description \\
\hline \multicolumn{3}{|c|}{ Displays sensitivity to individual, so cial and cultural differences } \\
\hline 11. Shows respect for all & 3.85 & Always Observed \\
\hline 12. Waits for one's turn & 3.62 & Always Observed \\
\hline $\begin{array}{l}\text { 13. Takes good care of borrowed } \\
\text { things }\end{array}$ & 3.71 & Always Observed \\
\hline $\begin{array}{l}\text { 14. Views mistakes as learning } \\
\text { opportunities }\end{array}$ & 3.79 & Always Observed \\
\hline $\begin{array}{l}\text { 15. Volunteers to assist others in } \\
\text { times of need }\end{array}$ & 3.51 & Always Observed \\
\hline $\begin{array}{l}\text { 16. Recognizes and respects } \\
\text { people from different economic, } \\
\text { social, and cultural backgrounds }\end{array}$ & 3.81 & Always Observed \\
\hline Mean & 3.72 & Always Observed \\
\hline \multicolumn{3}{|c|}{ Demonstrates contribution towards solidarity } \\
\hline 17. Cooperates during activities & 3.58 & Always Observed \\
\hline $\begin{array}{l}\text { 18. Recognizes and accepts the } \\
\text { contribution of others toward a } \\
\text { goal }\end{array}$ & 3.74 & Always Observed \\
\hline 19. Considers diverse views & 3.78 & Always Observed \\
\hline 20. Communicates respectfully & 3.74 & Always Observed \\
\hline $\begin{array}{l}\text { 21. Accepts defeat and celebrates } \\
\text { others' success }\end{array}$ & 3.79 & Always Observed \\
\hline 22. Enables others to succeed & 3.74 & Always Observed \\
\hline  & 3.41 & Sometimes Observed \\
\hline Mean & 3.68 & Always Observed \\
\hline Overall & 3.69 & Always Observed \\
\hline
\end{tabular}

When the students were surveyed about the indicators of Makatao core value, they generally responded that they always display sensitivity to individual, social and cultural differences (3.72) and demonstrate contribution towards solidarity (3.68). For them, the textbook writing activities reflected their ability to work with their groupmates. The responses of the students from the reflective questions validate the findings as many shared that the activity provided spaces for them to communicate and display respect for the diverse perspectives. Accordingly, they always respect the opinion of others during their planning and ideation process. They generally believe that the tasks encouraged active participation of every which contributed to building camaraderie between and among them.

It can be noted however that only one indicator was found to be sometimes observed by the pre-service teachers. This is the: speaks out against and prevents bullying (3.41). This is because some shared that they sometimes tease each other to ease the tasks they are doing.

\section{Makakalikasan}

The respondents were also asked about their experience of observing the Makakalikasan core value indicators. Table 4 shows the observed Makakalikasan core value while the preservice teachers are accomplishing the textbook writing tasks.

TABle IV. ObServed Makakalikasan Core VAlues Among PreSERVICE TEAHERS

\begin{tabular}{|c|c|c|}
\hline Indicators & Mean & Description \\
\hline \multicolumn{3}{|c|}{$\begin{array}{l}\text { Cares for the environment and utilizes resources wisely, judiciously and } \\
\text { economically }\end{array}$} \\
\hline $\begin{array}{l}\text { 24. Shows caring attitude towards the } \\
\text { environment }\end{array}$ & 3.52 & Always Observed \\
\hline 25. Practices waste management & 3.38 & Sometimes Observed \\
\hline 26. Conserves energy and resources & 3.26 & Sometimes Observed \\
\hline $\begin{array}{l}\text { 27. Takes care of school materials, } \\
\text { facilities and equipment }\end{array}$ & 3.68 & Always Observed \\
\hline $\begin{array}{l}\text { 28. Keeps work area in order during and } \\
\text { after work }\end{array}$ & 3.47 & Sometimes Observed \\
\hline 29. Keeps one's work neat and orderly & 3.53 & Always Observed \\
\hline Mean & 3.47 & Sometimes Observed \\
\hline
\end{tabular}

Table 4 displays that generally the pre-service teachers sometimes care for the environment and utilize resources wisely, judiciously and economically. From the table, it can noted that while they generally show care for the environment and take care of the school materials, facilities and equipment, they honestly recognize that they have spaces for improvement when it comes to energy and resources conservation, waste management and in keeping their work area in order. They shared that they sometimes forgot to unplug their computers and pack the things they use in accomplishing work. They honestly disclosed that these happen when they are already exhausted from the cognitive requirements of writing textbook

\section{Makabansa}

Table 5 shows the observed Makabayan core value indicators displayed by the pre-service teachers while accomplishing textbook writing tasks. The indicators are presented to categories. One category deals with their demonstration of pride in being Filipino and exercising their rights and responsibilities as Filipino citizens. On the other hand, the second category generally deals with their demonstration of appropriate behavior in carrying out activities in the school, community and country. 
TABLE V. ObServed MaKaKalikasan Core VAlues Among PreSERVICE TEAHERS

\begin{tabular}{|c|c|c|}
\hline Indicators & Mean & Description \\
\hline $\begin{array}{l}\text { Demonstrates } \\
\text { exercises the }\end{array}$ & \multicolumn{2}{|c|}{$\begin{array}{l}\text { in } \quad \text { being } \quad \text { Filipino, } \\
\text { and responsibilities of Filipino citizen }\end{array}$} \\
\hline 30. Identifies oneself as a Filipino & 3.89 & Always Observed \\
\hline $\begin{array}{l}\text { 31. Respects the flag and national } \\
\text { anthem }\end{array}$ & 3.92 & Always Observed \\
\hline $\begin{array}{l}\text { 32. Promotes the appreciation and } \\
\text { enhancement of Filipino languages }\end{array}$ & 3.76 & Always Observed \\
\hline $\begin{array}{l}\text { 33. Abides by the rules of the school, } \\
\text { community, and country }\end{array}$ & 3.72 & Always Observed \\
\hline $\begin{array}{l}\text { 34. Enables others to develop } \\
\text { interest and pride in being a Filipino }\end{array}$ & 3.70 & Always Observed \\
\hline Mean & 3.80 & Always Observed \\
\hline \multicolumn{3}{|c|}{$\begin{array}{l}\text { Demonstrate appropriate behavior in carrying out activities in the } \\
\text { school, community and country }\end{array}$} \\
\hline $\begin{array}{l}\text { 35. Manages time and personal } \\
\text { resources efficiently and effectively }\end{array}$ & 3.38 & $\begin{array}{l}\text { Sometimes } \\
\text { Observed }\end{array}$ \\
\hline $\begin{array}{l}\text { 36. Preserves to achieve goals } \\
\text { despite difficult circumstances }\end{array}$ & 3.71 & Always Observed \\
\hline $\begin{array}{l}\text { 37. Conducts oneself appropriately in } \\
\text { various situations }\end{array}$ & 3.54 & Always Observed \\
\hline Mean & 3.54 & Always Observed \\
\hline Overall Mean & 3.70 & Always Observed \\
\hline
\end{tabular}

Based on the results, the pre-service teachers always demonstrate almost all the indicators of being a Makabansa with an overall mean of 3.74 described as always observed. The pre-service teachers in the online survey declared that all indicators pertaining to the demonstration of their pride in being Filipino and their exercises of their rights and responsibilities as Filipino citizens are displayed by them while doing the textbook writing. The mean for this category is 3.80 value which is described as always observed. This result reflect that the pre-service teachers have somewhat internalize the emphasis of teaching Araling Panlipunan which to develop sense of nationalism and citizenship. Along the way, they probably reminded by the learning content they are writing.

On the other hand, the pre-service teachers strive to always demonstrate appropriate behaviour in carrying out activities in the school, community and the country with a mean of 3.54 however, it can be noted that they declare in the online survey that they sometimes observe management of time and personal resources efficiently and effectively. The above data show that the pre-service teachers have made efforts to manage their time and resources however, they still need to improve on this indicator. The responses they have on the open-ended reflections complement this result as they generally shared that one of the best things they learned from the course is the significance of managing the time and efficient and effective utilization of resources. This is also confirmatory with the data obtained in some of the Makakalikasan indicators on waste management and conservation of energy resources which are both described as sometimes observed.

To sum up, the engagement of pre-service teachers to textbook writing enables them to perform various life performance roles which are complementary to OutcomesBased Education frame. The roles they performed as they do tasks directly or indirectly shaped the Filipino core values. The activities implemented for the CPE 105 students to produce textbooks in Araling Panlipunan proved that OBE can serve as a vehicle for the development of the Filipino core values. This result also confirms the claim that $\mathrm{OBE}$ is promotive of the mandatory learning of the specific values-oriented content [16] since what the pre-service teachers have written were learning modules on Araling Panlipunan which are generally focused on the development of sense of nationalism among the Filipino children. This is probably the reason why the highest mean yielded is that of the Makabayan Core value indicators followed by Makatao core value indicators and then Makadiyos.

Generally, textbook writing tasks in OBE platform engage the students in collaborative learning- a significant foundation of active learning [17]. In collaboration with their team members, the pre-service teachers worked towards the production of textbook to apply the lessons they learned in Assessment in Learning 1. This real-world application evident in Assessment in Learning 1 class encouraged the pre-service teachers to engage deeply in the learning process. The preservice teachers were also given appropriate opportunities to prove that learned the knowledge and skills in designing, developing, selecting and using appropriate diagnostic, formative and summative assessment strategies in line with the $\mathrm{K}$ to 12 standards, guidelines, and requirements. Clearly, the implementation of learning following the principles of OBE such as clarity of focus, expanded opportunity, high expectations and design down [5] was successful in shaping unintended values (Filipino core values) as part of the learning process. The unintended learning of the Filipino core values among the pre-service teachers in the Assessment in Learning Class is a significant hidden curriculum which this research uncovered. Hidden curriculum according to Alsubaie, 2015 pertains to the 'unspoken or implicit values, behaviors, and norms' that is present during the teaching-learning process. In this study, there have been hidden curricular messages related to Filipino core values which the pre-service teachers have learned from various sources which the textbook writing tasks in OBE platform has provided [18].

\section{CONCLUSION}

The pre-service teachers have demonstrated Filipino core values such as Makabayan, Makatao, Makabansa and Makakalikasan as a result of their engagement to the processes involved in writing textbook in Araling Panlipunan. The Assessment in Learning 1 class delivered in Outcomes-Based Education has communicated hidden curricular messages that contribute to the development of Filipino core values among the pre-service teachers. A study to verify the extent of contribution of the textbook writing tasks to the Filipino core values is recommended to be carried out. Analysis of the academic outcomes of the pre-service teachers before and after the textbook writing activity is also suggested. 


\section{REFERENCES}

[1] G.S. Arquiza, 'Toward an Outcomes-Based Education Curriculum: A Philippine Higher Education Institution Experience,' 2017.

[2] C. Demirci, "The Effect of Active Learning Approach on Attitudes of 7th Grade Students", International Journal of Instruction, vol. 10 no. 4, pp. 129-144, 2017.

[3] N.J, Kwon, and E.H. Lee, "The effects of task-based learning strategies on the science process skills and the scientific attitudes of elementary school students". Journal of Korean Elementary Science Education, vol. 26, no. 2, pp. 141-148 2007.

[4] C. Mercado, and H. Lagto, "Understanding the readiness of implementing outcome-based education among selected higher education institutions in Philippines" AU-eJournal of Interdisciplinary Research (ISSN: 2408-1906), 3(1), 2018.

[5] W. Spady, W. Hussain, J. Largo, and F.A. Uy, Beyond Outcomes of Accreditation: Exploring the Power of 'Real' OBE Practices. Rex Book Store. Manila, Philippines, 2018.

[6] D.B. Jani, A.B. Abdul Latif, R.B. Talib, and N.B. Mohd Is, "The implementation of constructive alignment at the teachers education institute using rasch analysis," Journal of Critical Reviews ISSN- 23945125 Vol 7, Issue 11, 2020

[7] M.F. De Guzman, Edaño, C. Domingo and Z.D. Umayan, "Understanding the Essence of the Outcomes-Based Education (OBE) and Knowledge of its Implementation in a Technological University in the Philippines," Asia Pacific Journal of Multidisciplinary Research, Vol. 5, No. 4, 2017.

[8] F. Bouslama, M. Housley, and A. Steele,. "Using a fuzzy logic-based emotional intelligence framework for testing emotional literacy of students in an outcomes-based educational system," Journal of Network and Innovative Computing, vol. 3, pp. 105-114, 2015.

[9] P.O. Gandhi, Outcomes-Based Education. Queen_Mary_University_of_London.DO 10.13140/RG.2.2.14398.89923, 2002.
[10] R.A.A. Ortega and R.A.O.D. Cruz, "Educators' Attitude towards Outcomes-Based Educational Approach in English Second Language Learning," American Journal of Educational Research, vol. 4, no. 8, pp. 597-601. 2016.

[11] J.N. Fuertes, P. Anand, A. Toporovsky, A. Wolpoff, M. Reyes, F.C. Hungria and M. Taborga, "A Training Program in Working Alliance Communication Skills". Medical Science Educator, vol. 29, no. 4, pp. 987-994, 2019.

[12] M. Guzman, "Preferred student-centered strategies in teacher education: Input to outcomes-based instruction". Asia Pacific Journal of Education, Arts and Sciences, vol. 3, no. 1, pp. 40-48, 2016.

[13] P. Anderson, C.M. Anson, R.M. Gonyea, and C. Paine. "The contributions of writing to learning and development: Results from a large-scale multi-institutional study". Research in the Teaching of English, pp. 199-235, 2015.

[14] S. Lee., D.H. Kim, and S.M. Chae. "Self-directed learning and professional values of nursing students. Nurse Education in Practice", no. 42, pp. 102647. 2020.

[15] C. Hursen, "The impact of curriculum developed in line with authentic learning on the teacher candidates' success, attitude and self-directed learning skills," Asia Pacific Education Review, vol. 17, no. 1, pp. 73$86,2016$.

[16] W.F. Cox Jr, A.A. Arroyo, E.R. Tindall, and M.V. Uecker, M.V. "Outcome-Based Education: A Critique of the Theory, Philosophy, and Practice," Journal of research on Christian Education, vol. 6, no. 1, pp. 79-94, 1997.

[17] D.W. Johnson and R.T. Johnson,. "Social interdependence theory and cooperative learning: The teacher's role," In The teacher's role in implementing cooperative learning in the classroom (pp. 9-37). Springer, Boston, MA, 2008.

[18] M.A. Alsubaie,. "Hidden curriculum as one of current issue of curriculum". Journal of Education and Practice; vol. 6, no.33, pp. 125$128,2015$. 